\title{
PEMETAAN HIDROGEOLOGI WILAYAH BARAT DAYA KABUPATEN SERANG, BANTEN, INDONESIA
}

\author{
Ahmad Cahyadi', , Romza Fauzan Agniy ${ }^{2}$, Nurul Khakhim ${ }^{3}$, Setyawan Purnama1, \\ Igor Yoga Bachtiar ${ }^{4}$, and Wikan Jaya Prihartanto ${ }^{5}$
}

${ }^{1}$ Department of Environmental Geography, Faculty of Geography, Universitas Gadjah Mada, Indonesia

${ }^{2}$ Master on Planning and Management of Coastal Area and Watershed, Faculty of Geography,

Universitas Gadjah Mada, Indonesia

${ }^{3}$ Department of Geographic Information Science, Faculty of Geography, Universitas Gadjah Mada, Indonesia

${ }^{4}$ The Ministry of Agrarian Affairs and Spatial Planning/ National Land Agency, Indonesia

${ }^{5}$ Master Program on Remote Sensing, Faculty of Geography, Universitas Gadjah Mada, Indonesia

Email: ahmadcahyadi@geo.ugm.ac.id

Perkembangan wilayah Kota Serang sebagai pusat pemerintahan Provinsi Banten menyebabkan semakin banyaknya kebutuhan air bersih di lokasi tersebut dan wilayah sekitarnya. Penelitian ini bertujuan untuk melakukan pemetaan hidrogeologi wilayah di bagian barat daya Kabupaten Serang. Keempat wiayah ini selain menjadi sumber air bersih bagi Kota Serang juga menjadi wilayah penyangga yang direncanakan sebagai wilayah pengembangan perikanan air tawar dan pertanian lahan basah. Lokasi penelitian meliputi empat kecamatan yaitu Kecamatan Baros, Kecamatan Padarincang, Kecamatan Pabuaran dan Kecamatan Ciomas. Pemetaan hidrogeologi di lokasi kajian diharapkan dapat menjadi salah satu masukan dalam perencanaan penggunaan sumberdaya air. Metode yang digunakan dalam penelitian ini adalah dengan melakukan analisis data bor, hasil pengukuran geofisika, hasil penelitian sebelumnya, peta hidrogeologi skala 1:250.000, analisis geologi skala 1:100.000, pemetaan geomorfologi dan survei lapangan. Hasil penelitian menghasilkan enam kelas satuan hidrogeologi yang meliputi wilayah dengan produktivitas airtanah langka sampai dengan wilayah dengan produktivitas airtanah tinggi.

Keywords: Hydrogeological Mapping, Hydrogeology, Groundwater, Serang District

\section{INTRODUCTION}

Kota Serang, Provinsi Banten berkembang cukup pesat sejak menjadi Ibu Kota Provinsi Banten tahun 2000 [1]. Provinsi Banten adalah provinsi baru di Indonesia yang dahulunya merupakan bagian dari Provinsi Jawa Barat [2]. Sebagai ibu kota Provinsi, Kota Serang mengalami pembangunan yang pesat untuk dapat mendukung fungsinya sebagai lbu Kota Provinsi [3]. Pembangunan ini menyebabkan 
semakin banyaknya sumberdaya yang dibutuhkan untuk memenuhi kebutuhan bagi kota ini, di antaranya adalah sumberdaya air.

Perkembangan Kota Serang tidak hanya berdampak pada kondisi lingkungan di kota tersebut, tetapi juga berdampak bagi wilayah penyangga yang terdapat di sekitarnya. Dampak ini di antaranya nampak dari pengambilan air bersih dari bagian Barat Daya Kota dan pemanfaatan ruang yang dialokasikan untuk mendukung pemenuhan kebutuhan pangan seperti pertanian dan perikanan. Hal ini tentunya harus disikapi dengan melakukan kajian terkait dengan potensi sumberdaya air untuk menghindari kerusakan terhadap sumberdaya.

Penelitian ini bertujuan untuk melakukan pemetaan hidrologi skala 1:50.000 di bagian barat daya Kabupaten Serang, Provinsi Banten. Lokasi ini merupakan sumber air bersih bagi Kota Serang dan kawasan penyangga yang difungsikan untuk pengembangan pertanian lahan basah dan perikanan. Lokasi kajian meliputi empat kecamatan, yaitu Kecamatan Baros, Kecamatan Ciomas, Kecamatan Pabuaran dan Kecamatan Padarincang. Hal pokok yang harus disiapkan sebelum melakukan pengelolaan airatanah adalah karakteristik hidrogeologi suatu wilayah [4], [5], [6], [7]. Data hidrogeologi tersebut meliputi data karakteristik akuifer yang dapat dilihat dari data bor, data pengukuran geofisika, data uji pompa, data kenampakkan hidrogeologi seperti struktur batuan, jenis batuan, keberadaan mataair, danau, telaga dan sungai serta gua dan sungai bawah tanah untuk kawasan yang didominasi oleh proses pelarutan [8], [9], [10]. Oleh karenanya keberadaan data dasar (data base) hidrogeologi (dalam hal ini berupa peta hidrogeologi) merupakan hal yang sangat penting keberadaannya [11], [12], [13], [14], [15]. Peta ini nantinya dapat digunakan sebagai dasar pembuatan rencana pengelolaan sumberdaya airtanah yang berkelanjutan di suatu wilayah.

\section{METHODOLOGY}

\section{Analisis Kondisi Curah Hujan}

Curah hujan merupakan salah satu potensi sumber daya air pada suatu wilayah [16]. Hal tersebut tidak lepas dari siklus hidrologi yang memposisikan hujan sebagai imbuhan utama sumberdaya air pada suatu wilayah [17]. Curah hujan wilayah dapat dihitung berdasarkan data curah hujan yang terekam pada stasiun hujan yang terpasang di wilayah kajian ataupun berada di sekitar wilayah kajian yang masih mampu merepresentasikan besar curah hujan yang jatuh di wilayah kajian tersebut [18]. Metode penentuan curah hujan wilayah dilakukan dengan menggunakan membuat Isohyet. Interpolasi antar 
stasiun hujan yang saling berdekatan dapat merepresentasikan sebaran besar curah hujan yang jatuh di wilayah kajian.

Data yang digunakan untuk menghitung curah hujan wilayah di di lokasi kajian adalah data curah hujan yang terekam pada 5 stasiun hujan di dalam lokasi kajian dan sekitarnya. Rentang data yang digunakan dalam penelitian ini hanya 5 tahun sesuai dengan ketersediaan data yang ada. Data diperoleh dari Badan Meteorologi, Klimatologi dan Geofisikan Kabupaten Serang. Data curah hujan yang digunakan dalam penelitian ini disajikan dalam Tabel 1. Pembuatan isohyet dilakukan dengan menggunakan metode interpolasi dari posisi stasiun curah hujan yang ada [19]. Interpolasi dilakukan dengan memanfaatkan tools geostatistik yang ada dalam software ArcGis 10.2.

Tabel 1. Data Curah Hujan Tahunan 5 Stasiun Hujan Wilayah Kajian

\begin{tabular}{|c|c|c|c|c|c|c|c|c|}
\hline \multirow{2}{*}{ Stasiun } & \multirow{2}{*}{ Longitude } & \multirow{2}{*}{ Latitude } & \multicolumn{5}{|c|}{ Curah Hujan Tahunan (mm) } & \multirow{2}{*}{$\begin{array}{c}\text { Rerata } \\
\text { Tahunan } \\
\text { (mm) }\end{array}$} \\
\hline & & & 2011 & 2012 & 2013 & 2014 & 2015 & \\
\hline Baros & $106^{0} 13^{\prime} 28^{\prime \prime}$ BT & $06^{0} 21^{\prime} 55^{\prime \prime}$ LS & 1,403 & 1.376 & 2.301 & 1.897 & 1.237 & 1.643 \\
\hline Ciomas & $106^{\circ} 03^{\prime} 45^{\prime \prime}$ ВT & $06^{0} 22^{\prime} 83^{\prime \prime}$ LS & 2,210 & 2.400 & 3.672 & 2.827 & 2.514 & 2.725 \\
\hline Pabuaran & $106^{\circ} 07^{\prime} 19^{\prime \prime}$ ВT & $06^{0} 20^{\prime} 53^{\prime \prime}$ LS & 1,978 & 1.604 & 2.712 & 2.289 & 1.957 & 2.108 \\
\hline Padarincang & 105093' 31" BT & $06^{0} 22^{\prime} 02^{\prime \prime}$ LS & 2,352 & 2.703 & 3.764 & 2.468 & 2.374 & 2.732 \\
\hline Serang & $106^{\circ} 07^{\prime} 91^{\prime \prime}$ BT & $06^{0} 06^{\prime} 69^{\prime \prime}$ LS & 1,142 & 1.187 & 2.271 & 1.520 & 1.304 & 1.485 \\
\hline
\end{tabular}

Sumber: BMKG Kabupaten Serang tahun (2016)

\section{Pemetaan Hidrogeologi}

Pemetaan hidrogeologi di lokasi kajian dilakukan dengan melakukan analisis data bor, hasil pengukuran geofisika, hasil penelitian sebelumnya, peta hidrogeologi skala 1:250.000, analisis geologi skala 1:100.000, pemetaan geomorfologi dan survei lapangan. Peta hidrogeologi yang dihasilkan dari penelitian ini adalah peta hidrogeologi dengan skala 1:50.000. Pemetaan dilakukan dengan pendekatan satuan hidrogeomorfologi, yang telah diaplikasikan oleh banyak ahli sebelumnya [20], [21]. Pemetaan detail utamanya dilakukan dengan mempertimbangkan karakteristik bentuk lahan yang terdiri dari morfologi, struktur aktif dan pasif, proses, genesis dan umur (stadia) [21]. 
Paper ini merupakan versi preprint dari makalah berjudul "The Hydrogeological Mapping of the Southwestern Part of Serang Regency, Banten, Indonesia". Versi Bahasa Inggris dari paper ini kami submit ke International Conference on Science and Technology (ICST) tahun 2018 di Universitas Gadjah Mada Yogyakarta

\section{RESULTS AND DISCUSSION}

\section{Curah Hujan di Lokasi Kajian}

Hasil interpolasi data hujan ditunjukkan pada Gambar 1. Gambar satu merupakan hasil analisis dengan geostatistik Kriging. Dalam penelitian ini, data ini memiliki sebaran data yang paling sesuai dengan metode tersebut, dan memiliki nilai error yang kecil. Garis isohyet pada peta merepresentasikan besar curah hujan yang sama pada wilayah yang dilalui garis sesuai nilai curah hujan pada garis tersebut. Peta Isohyet yang dibuat memiliki interval besar curah hujan $100 \mathrm{~mm}$.

Curah hujan tahunan daerah kajian memiliki rentang $1.600 \mathrm{~mm}$ hingga $2.700 \mathrm{~mm}$. Selain itu, peta isohyet juga menunjukan bahwa curah hujan yang lebih tinggi terdapat pada bagian barat baratdaya. Wilayah tersebut meliputi Kecamatan Ciomas dan Padarincang dengan nilai tertinggi 2.700 $\mathrm{mm}$. Semakin kearah timur - timurlaut curah hujan menunjukan penurunan hingga pada nilai $1.600 \mathrm{~mm}$. Kondisi tersebut disebabkan karena faktor orografis dari Gunungapi Karang. Arah hadap lereng dan ketinggian yang ada Kecamatan Ciomas dan Padarincang menyebabkan uap air dari Laut Jawa tertahan pada lokasi tersebut dan mengahasilkan hujan orografis. Curah hujan yang cukup tinggi memungkinkan terjadinya jumlah imbuhan airtanah yang besar di lokasi kajian.

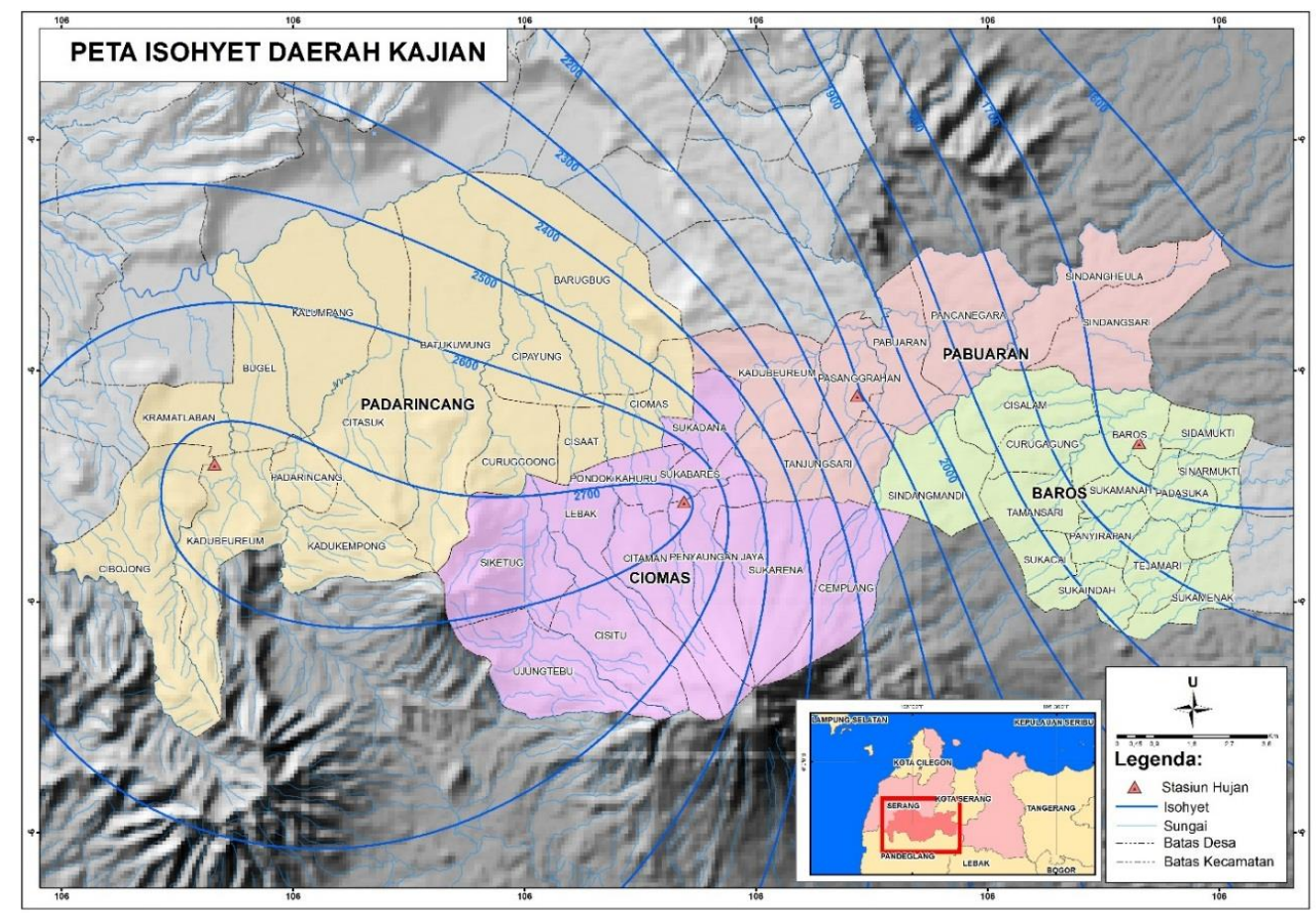

Gambar 1. Peta Isohyet Lokasi Kajian 
Paper ini merupakan versi preprint dari makalah berjudul "The Hydrogeological Mapping of the Southwestern Part of Serang Regency, Banten, Indonesia". Versi Bahasa Inggris dari paper ini kami submit ke International Conference on Science and Technology (ICST) tahun 2018 di Universitas Gadjah Mada Yogyakarta

\section{Kondisi Hidrogeologi dan Potensi Airtanah di Lokasi Kajian}

Peta hidrogeologi lokasi kajian pada Gambar 2 menunjukan informasi komposisi litologi dan kelulusan batuan, sebaran mataair, serta informasi ketersediaan airtanah dan produktifitas akuifer. Setidaknya terdapat 4 komposisi litologi permukaan yang ada di lokasi kajian. Keempat komposisi litologi permukaan tersebut adalah endapan volkanik muda, endapan aluvium, Tufa Banten, dan lava andesit. Komposisi endapan volkanik muda menjadi paling dominan di daerah kajian yang tersebar dari sisi barat hingga timur. Endapan aluvium hanya terdapat pada bagian baratlaut daerah kajian yang berasosiasi dengan keberadaan Rawa Danau yang merupakan bekas kawah volkanik. Tufa Banten menjadi komposisi litologi daerah kajian yang berada pada bagian timurlaut. Komposisi litologi lava andesit terindikasi berada pada bagian selatan daerah kajian yang berasosiasi dengan keberadaan Gunungapi Karang.

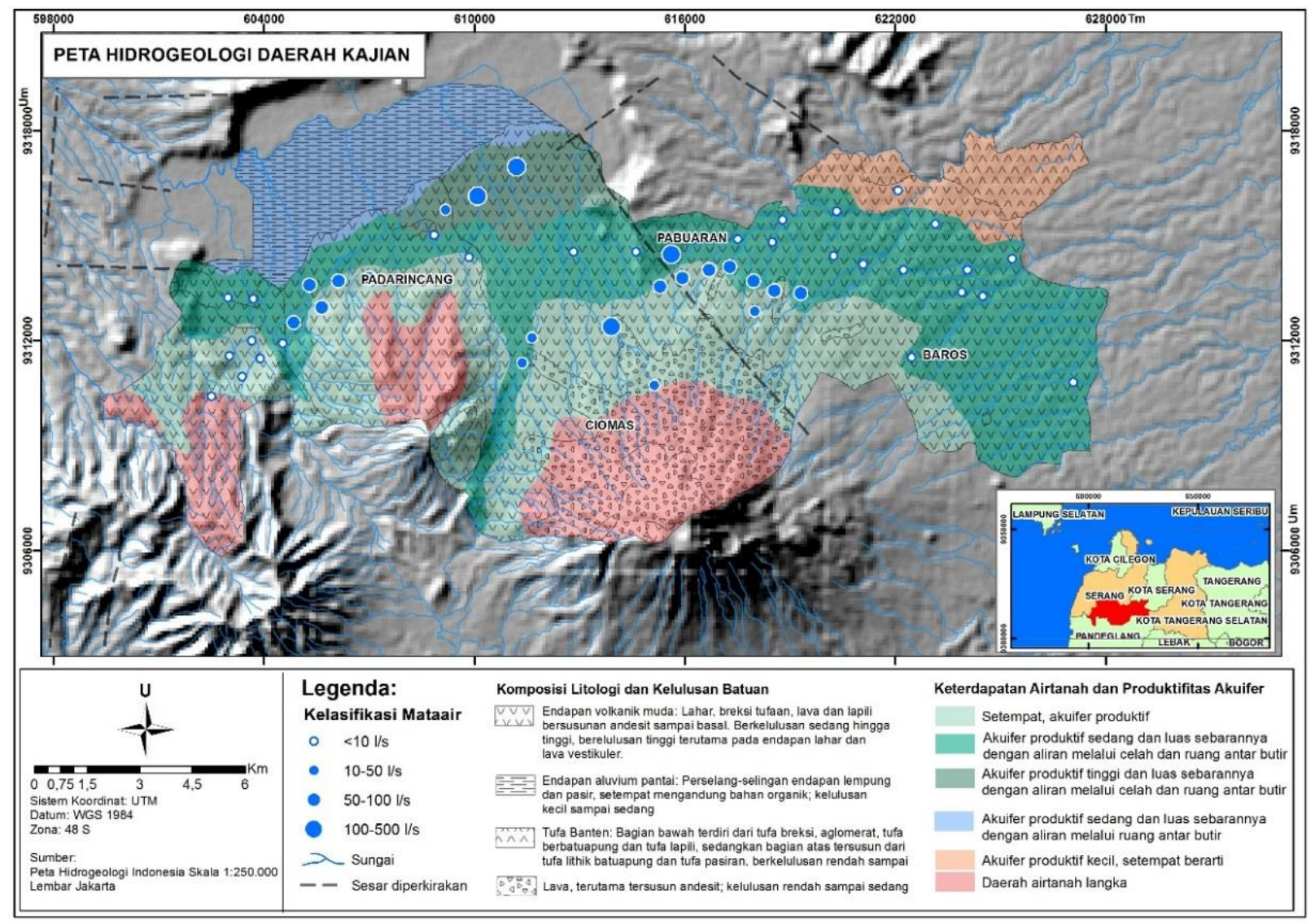

Gambar 2. Peta Hidrogeologi Daerah Kajian 
Informasi hidrogeologi lain yang dapat diketahui dari Peta Hidrogeologi Daerah Kajian adalah keterdapatan airtanah dan produktifitas akuifer. Terdapat 3 jenis kondisi keterdapatan airtanah dan produktifitas akuifer (kelompok akuifer) pada daerah kajian. Nemun demikian, masing-masing jenis tersebut kemudian dirinci menjadi enam kelas satuan hidrogeologi.

Pertama, kelompok akuifer dengan aliran celah dan ruang antar butir. Klasifikasi ini terbagi menjadi 3 jenis kondisi pada lokasi kajian, yaitu akuifer produktif dengan sebaran setempat, akuifer produktivitas sedang dengan sebaran luas, dan akuifer produktivitas tinggi dengan sebaran luas. Akuifer produktif dengan sebaran setempat menggambarkan akuifer dengan permeabilitas sangat beragam; umumnya tidak ditemukan airtanah yang dapat dimanfaatkan sekalipun dengan melakukan pengeboran. Hal ini karena muka airtanah cukup dalam. Lokasi ini ditandai dengan adanya mataair setempat yang dapat dikembangkan dengan debit kecil. Kondisi kedua adalah klasifikasi akuifer dengan aliran celah dan ruang antar butir yang merupakan akuifer produktif sedang dengan sebaran luas. Klasifikasi ini merupakan akuifer dengan permeabilitas sangat beragam; kedalaman airtanah tidak tertekan umumnya dalam dan debit sumur umumnya kurang dari 5 liter/detik. Kondisi ketiga yang ada di daerah kajian merupakan klasifikasi akuifer dengan aliran celah dan ruang antar butir akuifer produktif tinggi dengan sebaran luas. Klasifikasi ini merupakan akuifer dengan permeabilitas beragam; kedalaman airtanah beragam dan debit sumur umumnya lebih dari 5 liter/detik.

Kondisi akuifer kedua di lokasi kajian adalah termasuk dalam kelompok klasifikasi akuifer dengan aliran melalui ruang antar-butir yang merupakan akuifer produktivitas sedang dengan sebaran yang luas. Kondisi ini terdapat pada litologi endapan aluvium yang berada pada kawasan Rawa Danau Kecamatan Padarincang. Kondisi airtanah ini merepresentasikan akuifer dengan permeabilitas sedang sampai rendah, muka airtanah beragam dari atas sampai jauh di bawah permukaan tanah seperti yang terdapat di daerah padat industri, debit sumur kurang dari 5 liter/detik.

Kelompok klasfikasi akuifer ketiga di lokasi kajian merupakan kelompok klasifikasi akuifer bercelah atau sarang dengan produktivitas kecil dan wilayah airtanah langka. Terdapat dua kondisi pada kelompok akuifer ini, yaitu akuifer produktivitas kecil dengan sebaran setempat dan wilayah airtanah langka. Akuifer produktivitas kecil bersifat setempat dan menunjukan permeabilitas yang umumnya rendah sampai sangat rendah. Airtanah secara setempat (luasan yang sempit dan acak) dalam jumlah terbatas dapat diperoleh terutama pada daerah lembah atau zona pelapukan batuan masif. Wilayah airtanah langka pada peta hidrogeologi menunjukan kondisi yang benar-benar sulit didapatkan airtanah. 
Sebaran dan luas 6 jenis kondisi keterdapatan airtanah dan produktivitas akuifer (satuan hidrogeologi) pada lokasi kajian dapat dilihat pada Gambar 1 dan pada Tabel 1. Gambar 1. yang merupakan Peta Hidrogeologi Daerah Kajian dapat menunjukan sebaran masing-masing kondisi keterdapatan airtanah dan produktivitas akuifernya. Sebaran paling dominan adalah pada kelompok klasifikasi kelompok klasifikasi akuifer dengan aliran celah dan ruang antar butir dengan ketiga jenis kondisinya. Tabel 1. menunjukan kalkulasi luasan masing-masing kondisi keterdapatan airtanah dan produktivitas akuifer pada lokasi kajian. Jenis kondisi lakuifer produktif sedang dan luas sebarannya dengan aliran melalui celah dan ruang antar butir menjadi kondisi akuifer paling luas yaitu 7.477,07 hektar. Berdasarkan Tabel 1. dapat pula diketahui bahwa Kecamatan Padarincang merupakan kecamatan yang memiliki kondisi akuifer paling beragam. Hal ini karena pada kecamatan tersebut terdapat 5 kondisi akuifer dari 6 kondisi akuifer yang ada di daerah kajian.

Tabel 1. Luasan Kondisi Akuifer di Lokasi Kajian

\begin{tabular}{|l|r|r|r|r|r|}
\hline \multicolumn{1}{|c|}{ Kondisi Akuifer } & \multicolumn{3}{c|}{ Luas (Ha) } & $\begin{array}{r}\text { Total Luas } \\
\text { (Ha) }\end{array}$ \\
\cline { 2 - 6 } & \multicolumn{1}{|c|}{ Baros } & \multicolumn{1}{c|}{ Ciomas } & Pabuaran & Padarincang & \\
\hline $\begin{array}{l}\text { Akuifer produktivitas sedang dan luas } \\
\text { sebarannya dengan aliran melalui ruang } \\
\text { antar butir }\end{array}$ & 0,00 & 0,00 & 0,00 & $2.382,09$ & $\mathbf{2 . 3 8 2 , 0 9}$ \\
\hline $\begin{array}{l}\text { Akuifer produktif dengan aliran melalui } \\
\text { celah dan ruang antar butir dan sebaran } \\
\text { setempat }\end{array}$ & 959,73 & $2.557,92$ & 745,97 & $2.328,70$ & $\mathbf{6 . 5 9 2 , 3 2}$ \\
\hline $\begin{array}{l}\text { Akuifer produktivitas sedang, sebarannya } \\
\text { luas dengan aliran melalui celah dan } \\
\text { ruang antar butir }\end{array}$ & $2.803,46$ & 434,99 & $1.784,21$ & $2.454,41$ & $\mathbf{7 . 4 7 7 , 0 7}$ \\
\hline $\begin{array}{l}\text { Akuifer produktivitas tinggi, luas } \\
\text { sebarannya dengan aliran melalui celah } \\
\text { dan ruang antar butir }\end{array}$ & 0,00 & 0,00 & 0,00 & $1.205,36$ & $\mathbf{1 . 2 0 5 , 3 6}$ \\
\hline $\begin{array}{l}\text { Akuifer produktivitas kecil dengan } \\
\text { persebaran setempat }\end{array}$ & 0,00 & 0,00 & $1.296,50$ & 0,00 & $\mathbf{1 . 2 9 6 , 5 0}$ \\
\hline Wilayah airtanah langka & 0,00 & $2.511,63$ & 0,00 & $1.542,08$ & $\mathbf{4 . 0 5 3 , 7 1}$ \\
\hline
\end{tabular}

(Sumber: Hasil analisis data, 2018)

Informasi terakhir yang dapat diketahui dari peta hidrogeologi daerah kajian adalah keterdapatan mataair. Berdasarkan hasil inventarisasi yang dilakukan, setidaknya teridentifikasi 49 titik mataair. Berdasarkan besar debitnya, mataair di lokasi kajian dapat diklasifikasikan menjadi 4 seperti ditampilkan pada Tabel 2. Klasifikasi mataair dengan debit kurang dari 10 liter/detik merupakan 
klasifikasi dengan distribusi terbesar, yakni 28 mataair. Selain itu, Kecamatan Padarincang merupakan kecamatan kajian yang memiliki jumlah mataair paling banyak, yakni 21 mataair. Kemunculan mataair di lokasi kajian memiliki pola mengikuti tekuk lereng dari Gunungapi Karang. Kondisi ini juga ditemukan di wilayah lain seperti di Gunungapi Merapi [22] dan Gunungapi Lawu [23] di Provinsi Jawa Tengah. Selain itu, beberapa mataair muncul karena pengaruh patahan. Meskipun demikian, kemunculan mataair pada tekuk lereng atau sabuk mataair lebih dominan.

Tabel 2. Mataair di Lokasi Kajian

\begin{tabular}{|c|c|c|c|c|c|}
\hline \multirow{2}{*}{ Kecamatan } & \multicolumn{4}{|c|}{ Klasifikasi Mataair } & \multirow{2}{*}{$\begin{array}{l}\text { Jumlah } \\
\text { Mataair }\end{array}$} \\
\hline & $<10 \mathrm{l} / \mathrm{s}$ & $100-500 \mathrm{l} / \mathrm{s}$ & $10-50 \mathrm{l} / \mathrm{s}$ & $50-100 \mathrm{l} / \mathrm{s}$ & \\
\hline Baros & 6 & 0 & 0 & 0 & 6 \\
\hline Ciomas & 0 & 1 & 2 & 1 & 4 \\
\hline Pabuaran & 10 & 1 & 1 & 6 & 18 \\
\hline Padarincang & 12 & 2 & 2 & 5 & 21 \\
\hline Jumlah Mataair & 28 & 4 & 5 & 12 & 49 \\
\hline
\end{tabular}

Sumber: Hasil inventarisasi (2018)

\section{CONCLUSIONS}

Curah hujan tahunan di lokasi kajian berkisar antara $1.600 \mathrm{~mm}$ sampai dengan $2.700 \mathrm{~mm}$. Hal tersebut menunjukkan potensi imbuhan airtanah yang cukup besar. Selain itu, hasil analisis menunjukkan bahwa kondisi akuifer di lokasi kajian dapat diklasifikasikan menjadi 6 macam, yaitu (1) Akuifer produktivitas sedang dan luas sebarannya dengan aliran melalui ruang antar butir; (2) Akuifer produktif dengan aliran melalui celah dan ruang antar butir dan sebaran setempat; (3) Akuifer produktivitas sedang, sebarannya luas dengan aliran melalui celah dan ruang antar butir; (4) Akuifer produktivitas tinggi, luas sebarannya dengan aliran melalui celah dan ruang antar butir; (5) Akuifer produktivitas kecil dengan persebaran setempat dan (6) Wilayah airtanah langka. Hasil survei lapangan menunjukkan bahwa jumlah mataair di lokasi kajian berjumlah 49 mataair. Kemunculan mataair di lokasi kajian umumnya terjadi pada tekuk lereng yang kemudian nampak dari sebagai sabuk mataair dari Gunungapi Karang.

\section{ACKNOWLEDGMENTS}

Penelitian ini merupakan bagian dari penelitian berjudul "Kajian Potensi Budidaya Air Tawar Kabupaten Serang". Penelitian dilakukan atas kerjasama Fakultas Geografi Universitas Gadjah Mada dan Dinas Kelautan, Energi dan Sumberdaya Mineral Kabupaten Serang, Provinsi Banten. Penulis 
mengucapkan terimakasih kepada kedua pihak yang memberi kesempatan penulis menjadi bagian dari tim peneliti dalam penelitian tersebut.

\section{REFERENCES}

[1] A.P. Putra. Analisis Potensi dan Prioritas Pengembangan Pariwisata di Kota Serang Provinsi Banten. Bachelor Thesis. Surakarta, Universitas Muhammadiyah Surakarta. (2017)

[2] R.S. Wijono. Di Bawah Bayang-bayang Ibukota: Penataan Daerah Provinsi Banten dari Zaman Kolonial sampai Zaman Reformasi. Jurnal Sejarah Citra Lekha, 2(2), 126-142. (2017)

[3] Kantor Perwakilan Bank Indonesia Provinsi Banten. Kajian Ekonomi dan Keuangan Regional Provinsi Banten. Research Report. Serang, Bank Indonesia. (2017)

[4] R.C. Gogu, G. Carabin, V.Hallet, V. Peters, A. Dassargues. GIS-based Hydrogeological Database and Groundwater Modelling. Hydrogeology Journal, 9, 555-569. (2001)

[5] J.E. Moore. Field Hydrogeology: A Guide for Site Investigations and Report Preaparation. Boca raton, CRC Press. (2002)

[6] J. Margat, J. van der Gun. Groundwater Around the World. Boca Raton, CRC Press. (2013)

[7] R.T. Ranganai, M.D. Moidaki, J.G. King, Z.B. Bagai. Geophysical and Hydrogeological Groundwater Prospectivity Mapping in the Kraaipan Granite-Greenstone Terrain, Southeast Botswana. Journal of Water Resource and Protection, 9, 1270-1298. (2017)

[8] J. Terzic, F. Sumanovac, R. Buljan. An Assessment of Hydrogeological Parameters on the Karstic Island of Dugi Otok, Croatia. Journal of Hydrology, 343, 29-42. (2007)

[9] W.D. Weight. Hydrologeology Field Manual, Second Edition. New York, The McGRaw-Hill Companie, Inc. (2008)

[10] A. Cahyadi, I.A. Riyanto, N. Listyaningrum, S.F. Lestari. Pembuatan Data Dasar Hidrogeologi Daerah Istimewa Yogyakarta dan Provinsi Jawa Tengah. Research Report. Faculty of Geography, Universitas Gadjah Mada. (2017)

[11] S.Purnama, E. Febriarta, A. Cahyadi, N. Khakhim, L. Ismangil, H. Prihatno. Analisis Karakteristik Akuifer Berdasarkan Pendugaan Geolistrik di Pesisir Kabupaten Cilacap Jawa Tengah. Jurnal Geografi, 11(22), 155-165. (2013)

[12] S.M. Shirazi, Md.I. Adham, N.H. Zardari, Z. Ismail, H.Md. Imran, M.A. Mangrio. Groundwater Quality and Hydrogeological Characteristics of Malaca State in Malaysia. Journal of Water and Land Development, 24, 11-19. (2015) 
[13] H.I. Chamine, J.M. Carvalho, J. Teixeira, L. Freitas. Role of Hydrogeological Mapping in Groundwater Practice: Back to Basics. European Geologist, 40, 34-42. (2015)

[14] S. Suprayogi, S. Purnama, R.F. Agniy, A. Cahyadi. Potensi Airtanah Statis di Daerah Tangkapan Air Goa Pindul Kabupaten Gunungkidul. Proceeding of National Seminar on Environmental Geography I, Faculty of Geography, Universitas Gadjah Mada, (2016).

[15] Sunarto, A. Cahyadi, M.A. Marfai, S.H. Murti, H. Fatchurohman, M.N. Malawani. Karakteristik Akuifer Wilayah Kepesisiran Parangtritis, Kabupaten Bantul. Proceeding of National Seminar on Geography I, Faculty of Geography, Universitas Gadjah Mada. (2017)

[16] H. Nurrohmah, A. Cahyadi, Analisis Pemenuhan Kebutuhan Air Domestik dengan Airtanah di Daerah Aliran Sungai Kayangan Kabupaten Kulonprogo. Proceeding of National Seminar on Environmental Geography I, Faculty of Geography, Universitas Gadjah Mada, (2016).

[17] A. Cahyadi, F.A. Hartoyo. Pemanfaatan Sistem Informasi Geografis (SIG) untuk Pemetaan Imbuhan Airtanah dan Kerentanan Airtanah di Kawasan karst (Studi Kasus di Kecamatan Paliyan dan Kecamatan Saptosari, Kabupaten Gunungkidul). Proceeding of National Seminar on Information Technology Application, Universitas Islam Indonesia. (2011).

[18] H. Nurrohmah, Sudarmadji, A. Cahyadi. Kajian Kekeringan Meteorologis dan Kaitannya dengan Agihan Mata Air di Kabupaten Kulonprogo, Daerah Istimewa Yogyakarta. Proceeding of National Seminar on Environmental Geography I, Faculty of Geography, Universitas Gadjah Mada, (2016).

[19] S.H. Lai, M.S.M. Amin, P.L. Law, Y.S. Mah. Applications of GIS and Remote Sensing in the Hydrological Study of the Upper Bernam River Basin, Malaysia. Journal-The Institution of Engineers Malaysia, 69(1), 14-18. (2008)

[20] A.G. Brown. 1995. Geomorphology and Groundwater. Chichester, John Wiley and Sons.

[21] A. Cahyadi, A. Rofi, R. Harini. Pemetaan Potensi Airtanah di DAS Juwet Kabupaten Gunungkidul. Proceeding of National Seminar on Environmental Geography I, Faculty of Geography, Universitas Gadjah Mada, (2016).

[22] E. Nurjani, T.N. Adji, K.S. Harjo, A. Cahyadi. Inventarisasi Potensi Sumberdaya Air di Desa Wukirsari, Kecamatan Cangkringan untuk Menentukan Solusi Alternatif Akibat Kerusakan Jaringan Irigasi oleh Banjir Lahar Pasca Erupsi Merapi 2010. Research Report. Vocational College, Universitas Gadjah Mada. (2011)

[23] L.W. Santosa. Kajian Hidrogeologi Mataair di Sebagian Lereng Barat Gunungapi Lawu. Forum Geografi, 20(1), 68-85. (2006) 